\title{
Hukum Raja Deuteronomis (Ulangan 17:14-21): \\ Sebuah Upaya Analisis Teks
}

Analisis teks (kritik teks) berfungsi untuk mengadakan rekonstruksi teks pada masa penulisannya, yang diterima sebelum pengkanonan seluruh Alkitab. ${ }^{1}$ Teks yang tertera di atas mempunyai permasalahan yang ditandai dengan ${ }^{\text {a, b, c, dan d. Masalah }}$ yang ada pada beberapa ayat tersebut akan dipecahkan melalui metode kritik teks. Sedangkan ayat yang tidak bermasalah, tidak dibahas pada bagian ini.

\section{Ayat 14}

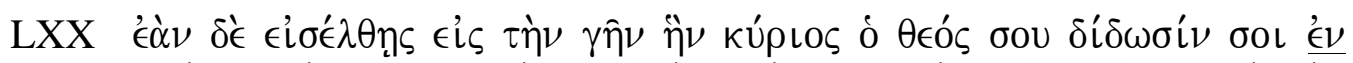

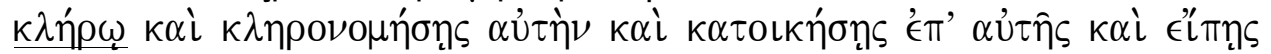

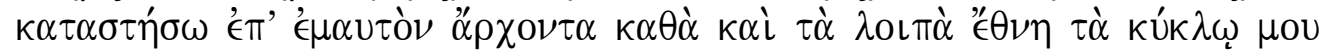

ITB Apabila engkau telah tiba ke negeri (itu) yang TUHAN, Allahmu berikan kepadamu menjadi milik pusaka, dan telah memilikinya dan diam di sana, kemudian engkau berkata: Aku mau mengangkat seorang raja atasku, seperti seluruh bangsa yang di sekelilingku.

Terdapat perbedaan antara teks Masora (MT) dan Septuaginta (LXX). Penerjemah LXX menambahkan kata $\epsilon \nu, \kappa \lambda \eta \rho \omega$

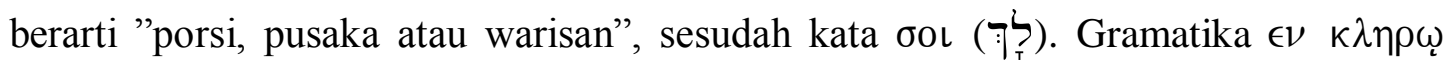
dan oo adalah sama, yakni berkasus datif. Kemungkinan penerjemah Septuaginta ingin menekankan perihal negeri yang diberikan Tuhan kepada Israel tersebut adalah

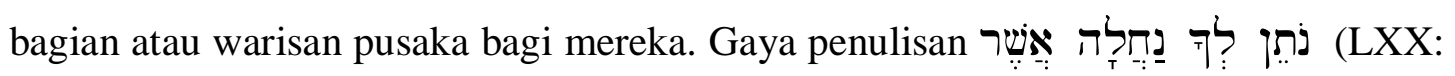

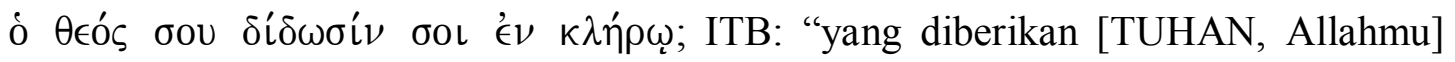

\footnotetext{
${ }^{1}$ A.A. Sitompul dan Ulrich Beyer, Metode Penafsiran Alkitab (Jakarta: BPK Gunung Mulia, ${ }^{14} 2009$ ), 36.
} 
kepadamu menjadi milik pusakamu") cukup sering dijumpai dalam Kitab Ulangan, antara lain terdapat pada $4: 21 ; 15: 4 ; 19: 10 ; 20: 16 ; 21: 28 ; 24: 4 ; 25: 19$; dan $26: 1$ (BDB, hal.635). Di luar Kitab Ulangan, penulis Dtr juga kerap kali menyandingkan נפתן dengan ("memberikan”), misalnya seperti yang dituliskan dalam Yos. 11:23; 14:3,13; 17:4; dan 19:49 (BDB: hal.635). Tidak mengherankan kalau penerjemah Septuaginta akhirnya menambahkan kata $\epsilon \nu$ $\kappa \lambda \eta \rho \omega$, demi kepentingan ciri khas dari kepenulisan Dtr. Melalui kalimat, “...ke negeri (itu) yang TUHAN, Allahmu berikan kepadamu..." saja, sebetulnya perihal kepemilikian Israel atas tanah Kanaan sudah jelas. Namun, dengan mempertimbangkan alasan penerjemah Septuaginta di atas, maka penulis pun memilih untuk memakai kata נִּחְלָה pada ayat ini. Jika diperhatikan, terjemahan LAI pun mengikuti terjemahan Septuaginta tersebut, sehingga bentuk kalimatnya menjadi, “...yang TUHAN, Allahmu berikan kepadamu menjadi milik pusaka...". Jadi, hasil kritik teks penulis terhadap ayat 14 adalah sebagai berikut:

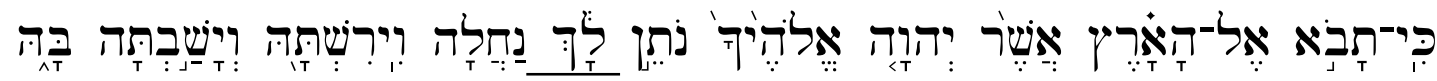

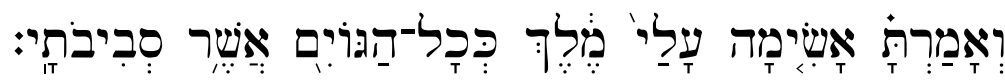

$\underline{\text { Ayat } 16}$

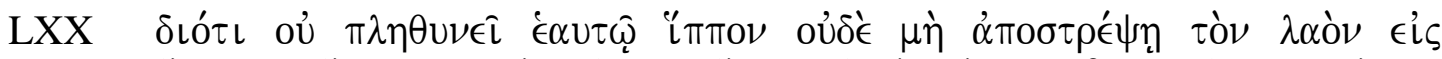

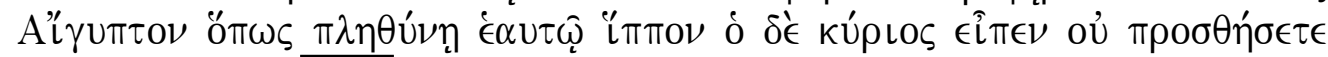

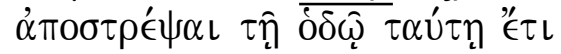

ITB Hanya, dia jangan memelihara banyak kuda untuk dirinya sendiri, dan jangan mengembalikan bangsa ini ke Mesir dalam rangka memperbanyak kuda untuk 
dirinya sendiri. Sebab TUHAN, Allahmu telah berfirman kepadamu (sekalian): Jangan pernah kamu sekalian kembali melalui jalan ini lagi.

Di dalam terjemahan Septuaginta kata $\epsilon \alpha u \tau \omega ̣$ diulang dua kali. Tetapi pada teks Masora kata $\epsilon \alpha v \tau \omega$ ( merupakan preposisi yang disertai dengan kata ganti orang ke-3 m.t., yang diartikan:

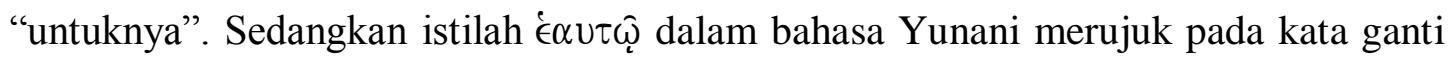
orang ke-3 m.t. berbentuk reflektif, yang diartikan: "untuk dirinya sendiri”. Di dalam BHS, kata ini diberi kode $\mathfrak{G}^{\text {-Ms }}\left(\boldsymbol{S} \mathbb{C} \mathbb{C}^{\mathrm{J}} \mathfrak{v}\right)+\epsilon \alpha \cup \tau \hat{\omega}$. Artinya, baik kodeks-kodeks terjemahan Yunani $\left(\boldsymbol{\mathfrak { J }}^{-\mathrm{Ms}}\right)$, Pesyitta $(\mathfrak{S})$, Targum $(\mathbb{\mathfrak { C }})$, Targum Pseudo-Yonatan/

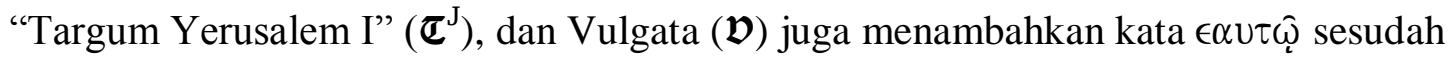

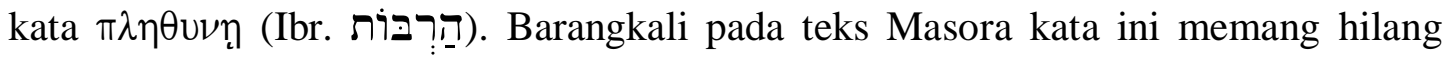
akibat rusaknya manuskrip awal, kemudian para penerjemah PL lainnya (Septuaginta, Pesyitta, Targum, dan Vulgata) menuliskan kembali kata ini. Tujuannya ialah menegaskan bahwa kuda-kuda yang diambil dari Mesir tersebut memang dipergunakan untuk kepentingan diri raja Israel sendiri. Kata לו 0 dalam frasa

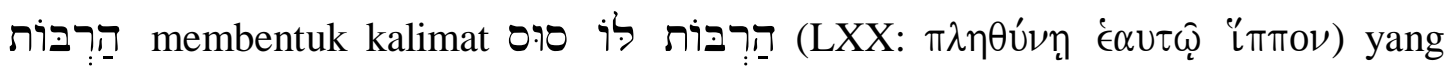
mengulangi frasa sebelumnya ירבְּה (LXX:sehingga terjadi pengulangan yang senada atau seirama. Karena itu, penulis memilih terjemahan Septuaginta sebagai terjemahan yang lebih tepat. Sementara itu, pada terjemahan ITB tidak tampak pemakaian kata לל (Yun. $\dot{\epsilon} \alpha \cup \tau \omega \hat{)})$, “...janganlah ia memelihara banyak kuda...untuk mendapatkan banyak kuda...”. 
Kata kedua yang perlu dicermati adalah הָפַָר yang diberi kode האמר $^{\mathrm{Ms}(\mathrm{s})}$ Kode ini menunjukkan bahwa berdasar pada terjemahan kodeks tulisan tangan teks Pentateukh berbahasa Ibrani dari orang Samaria (menurut A. von Gall) ${ }^{2}$, kata ini mendapat tambahan huruf $\pi$; mungkin sebuah awalan penentu. Tetapi awalan אמר אמר kenentu biasanya dikenakan kepada kata benda dan kata sifat, sementara (artinya: "berkata, berfirman") adalah kata kerja. Bentuk demikian (untuk kata אמר $+\pi)$ hanya muncul satu kali dalam teks Ibrani, yaitu dalam kitab Ayub 34:18, dengan bentuk (BDB, hal.55), yang diartikan, "Dia yang berfirman...". Jika mempertimbangkan terjemahan PL lainnya, bentuk kata tersebut aslinya memang tidak diberi awalan penentu $\pi$. Sedangkan apa yang tertulis pada teks Pentateukh Samaria yang berbahasa Ibrani, diperkirakan bahwa para penyalin menambahkannya kemudian. Jadi, penulis mempertahankan teks Masora dalam kitab BHS.

לְָָ adalah kata terakhir dari ayat 16 yang perlu diperhatikan, sebab di dalam

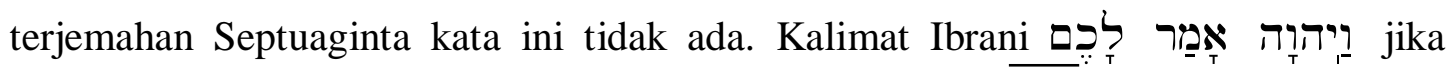
diartikan menjadi, “...sebab TUHAN telah berfirman kepadamu”. Sementara dalam

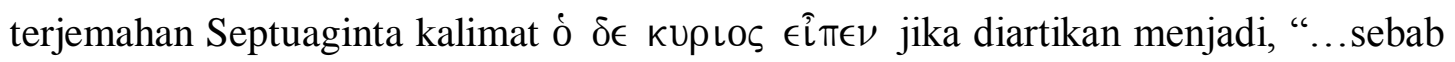
TUHAN telah berfirman" (tanpa kata 'kepadamu'). Tampaknya penerjemah Septuaginta menganggap tidak perlu menuliskan kepada siapa Tuhan berfirman, sebab hal itu sudah jelas. Sebaliknya, penulis menilai kata לִֶ לִם sangat penting

\footnotetext{
${ }_{2}^{2}$ Perjanjian Lama Ibrani-Indonesia (Jakarta: LAI, 2004).
} 
dituliskan untuk menunjukkan kepada siapa Tuhan memberikan firman-Nya. Dan lagi, hal ini sekaligus untuk memperjelas dua bentuk larangan Tuhan yang ada di dalam ayat ini. Pertama, larangan yang masih satu rangkaian perintah dalam ayatayat sebelumnya (14-15), “...janganlah ia (raja Israel) memelihara banyak kuda dan janganlah mengembalikan bangsa ini (Israel) ke Mesir...” (ay.16a); yang kedua, larangan yang sudah ada sebelum hukum raja ini ditulis, "Janganlah sekali-kali kamu (bangsa Israel) kembali melalui jalan ini lagi” (ay.16b). Di sini, kata לִֶ dipakai pada larangan bentuk kedua. Di samping itu, kata לְ לְ (akhiran kata ganti orang dengan preposisi ל?: "kepada/bagi”) juga tidak terdapat dalam tulisan tangan pertama (naskah asli) kodeks Vatikanus huruf kecil no.9; justru yang ada pada no.1 dan 107, yaitu kata אִ אִלי (akhiran kata ganti orang dengan preposisi "untuk"). Secara gramatikal kedua kata tersebut berbeda. Gramatika kata לֶָָ ialah orang ke-2.m.j., sedangkan gramatika kata אֵַ ארי ("untukku”) ialah orang ke-1.m.t.

Untuk memecahkan masalah ini, sebaiknya perhatikan kalimat selanjutnya,

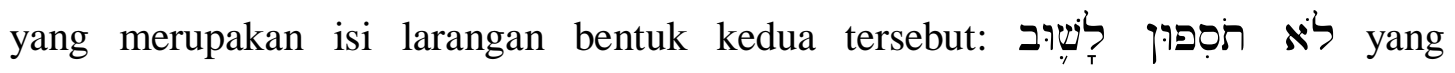
diterjemahkan “janganlah sekali-kali kamu (sekalian) kembali”. Gramatika kata תִספּּן "kamu (sekalian) kembali” adalah Hi.impf.2.m.j. Supaya numeriknya seimbang dan sesuai tata bahasa, maka kata לִ ְָ yang lebih tepat dipakai. Berdasarkan analisis di atas, penulis memutuskan untuk memakai teks Masora dalam BHS. Pada terjemahan ITB-LAI, numerik jamak dari kata לֶָ ("kepada kamu 
sekalian") memang tidak tampak. Dengan demikian, hasil kritik teks penulis terhadap ayat ini adalah sebagai berikut:

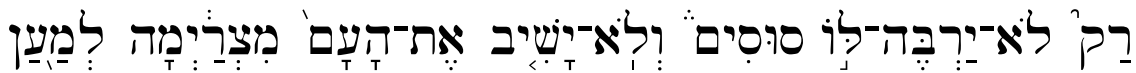

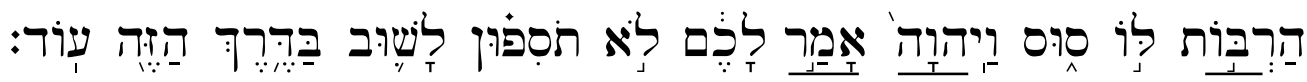

Ayat 18

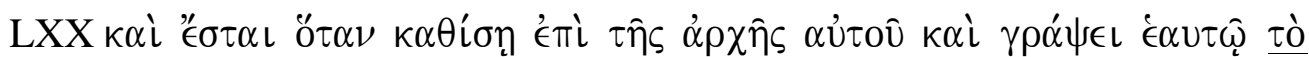

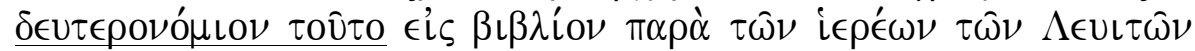

ITB Dan ketika dia duduk di atas tahta kerajaannya, ia akan menulis bagi dirinya sendiri salinan Taurat ini, menurut kitab yang dipegang para imam Lewi.

Terdapat dua permasalahan teks pada ayat ini. Yang pertama tidak dituliskannya kata

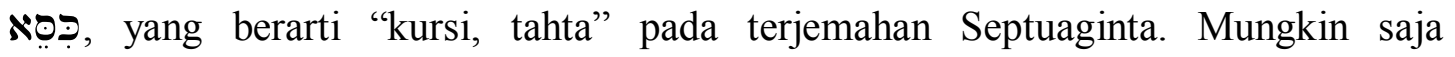
penerjemah Septuaginta menganggap kata ini memang tidak ada pada manuskrip

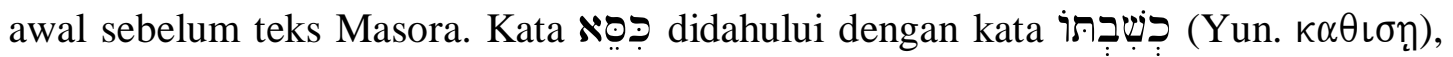
yang akar katanya dan artinya, "dia duduk”. Berdasarkan logika berpikir, sesudah kata "dia duduk" diperlukan kata keterangan yang merujuk pada "tempat" atau "lokasi" dia duduk; dalam hal ini yang dimaksudkan ialah "tahta" kerajaan. Sehingga

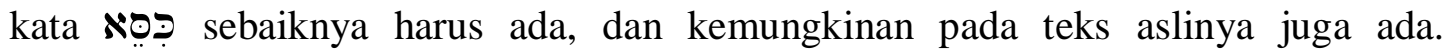
Terjemahan LAI pun mencantumkan kata ini sehingga menjadi, "Apabila ia duduk di atas tahta kerajaan,...”.

Permasalahan teks berikutnya terjadi pada lebih dari satu kata, yakni pada frasa

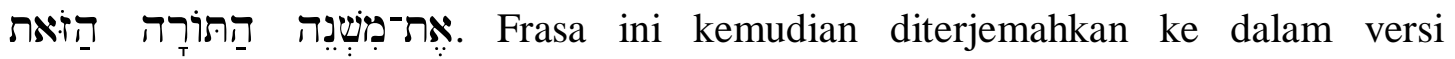




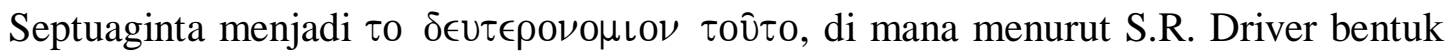
ini merupakan "a grammatical error" atau "ungrammatical". ${ }^{3}$ Meskipun judul Kitab Ulangan sekarang diambil dari terjemahan Septuaginta tentang istilah $\delta \in \cup \tau \epsilon \rho \nu \circ \mu \iota \nu \nu$, tetapi pengertian teks Ibrani lebih dipertahankan, yaitu "salinan hukum”. Hal ini juga terjadi pada terjemahan LAI. Pemakaian frasa yang mengarah kepada "salinan hukum" ini, hanya tercatat dua kali dalam PL. Yang pertama tentu saja pada ayat ini; yang kedua dicatat dalam Yos.8:32, “...dituliskan Yosua salinan

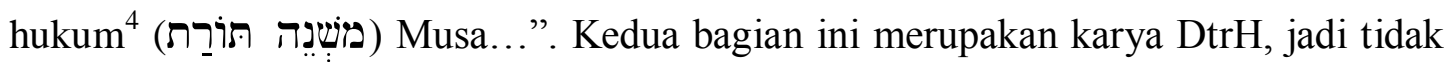
mengherankan kalau kedua kata itupun bisa memakai istilah yang sama. Jadi, hasil kritik teks untuk ayat ini adalah:

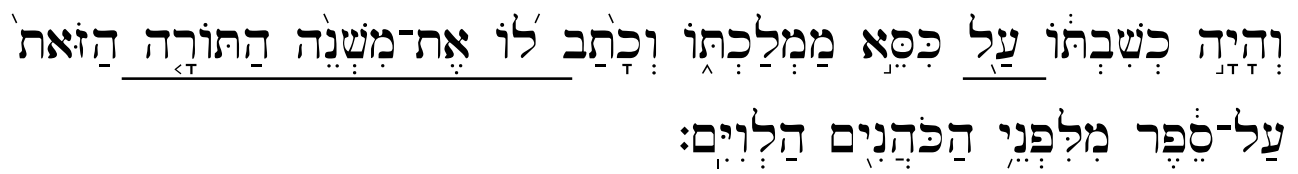

Ayat 19

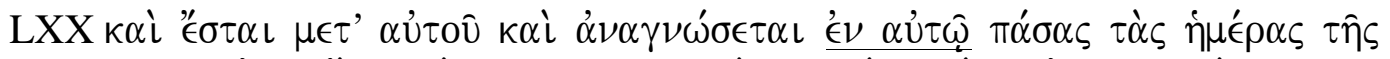

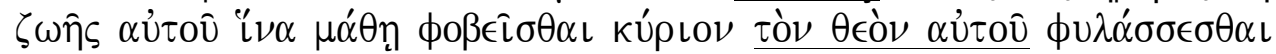

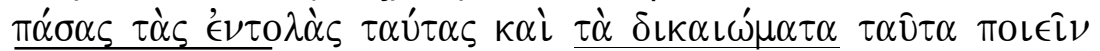

ITB Itulah yang harus ada dengannya, dan dia akan membaca(isi)nya seumur hidupnya supaya dia belajar takut akan TUHAN, Allahnya dengan berpegang pada seluruh perkataan Taurat dan ketetapan-ketetapan ini, serta melakukannya.

\footnotetext{
${ }^{3}$ S.R. Driver, A Critical and Exegetical Commentary on Deuteronomy (Edinburgh: T \& T Clark, 1973), i.

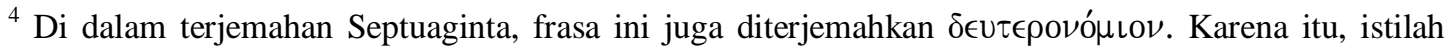
torâh pada ayat ini (Yos.8:32) harus diterjemahkan dan dipahami sebagai "hukum", sama seperti yang dimaksudkan dalam teks Hukum Raja (ay.18), bd. hal.94.
} 
Pada ayat ini, permasalahan teks yang pertama terjadi pada kata בר. Dalam BHS, kata ini diberi kode Seb yang berarti Sebir, maksudnya bagi para ahli Masora, kata ini bukan bentuk biasa dari tata bahasa Ibrani. Makanya penulis Masora menuliskan bentuk yang biasa di bagian pinggir halaman salinannya. Menurut mereka bentuk biasa dari kata ברָ adalah kata di mana terdapat juga dalam terjemahan Pentateukh Samaria (eu) dan Targum (⿻্飞). Kedua kata tersebut sama-sama berasal dari preposisi ב, hanya perbedaannya ( בר (bô) bergender maskulin, sedangkan (bāh) bergender feminim. Kata bô lebih tepat mengarah kepada "raja" karena bergender maskulin; dan kata $b \bar{a} h$ mengarah kepada "Hukum/ Taurat", karena bergender feminim. Kalimat ארְִ !ְ bila diterjemahkan menjadi, "dan dia harus membacanya...". Sufiks '-nya' dalam terjemahan ini pastilah merujuk kepada תזּרָרה (Taurat) itu. Sebab gender tentu saja feminim. Sehingga Sebir kaum Masora, terjemahan Pentateukh Samaria dan Targum adalah lebih tepat, yakni memakai kata $b \bar{a} h$. Sebab, gender kata $b \bar{a} h$ dan kata torah, keduanya berbentuk feminim.

Kata kedua yang perlu dianalisis adalah אֶלדיו (3.m.t.sf.) yang berarti, “Allahnya (raja)". Tetapi, menurut kodeks-kodeks Ibrani tulisan tangan versi B. Kennicott $\left(\mathrm{V}^{\mathrm{Ken} 69.107} \mathrm{Mss}\right)$ dan naskah asli Vatikanus $\left(\boldsymbol{\sigma}^{\mathrm{B} \Theta \mathrm{min}}\right)$ bentuk kata tersebut adalah (2.m/f.t.) yang berarti, “Allah-mu”. Letak perbedaannya yaitu antara huruf (waw) dan huruf $\rceil$ (kaf final) saja, yaitu sufiks untuk orang ke-3 dan ke-2. Apabila 
mengikuti kodeks tulisan tangan versi B. Kennicott dan kodeks Vatikanus, maka sufiks "mu" (kata ganti orang ke-2) yang dimaksud mestinya "bangsa Yehuda/ umat". Dan memang pada ayat-ayat sebelumnya, setiap kali penggunaan sufiks "-mu” adalah untuk umat. Sebenarnya ayat 19 adalah bagian dari kelompok teks ayat 16-17, yang diperkirakan berasal dari sumber yang sama. ${ }^{5}$ Untuk lapisan sastra bagian ini (16-17), kata ganti orang yang dipakai adalah kata ganti orang ke-3.m.t., sebab yang sedang dibahas penulis adalah sosok raja, bukan bangsa Israel/ Yehuda. Oleh karena itu, kata אלהיזי: yang penulis tetapkan untuk dipakai, sehingga tetap mengikuti teks Masora pada kitab Ibrani versi BHS. Dan bentuk terjemahan demikian, juga diikuti oleh penerjemah LAI.

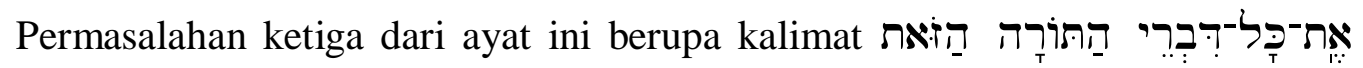
yang artinya, "pada segala perkataan dari hukum (Taurat) ini”. Di dalam terjemahan Septuaginta terlihat berbeda, perhatikan kalimat ini: $\pi \alpha \sigma \alpha \varsigma \tau \alpha \varsigma \in \nu \tau 0 \lambda \alpha \varsigma \tau \alpha \nu \tau \alpha \varsigma$. Kata ("דִברִי ('perkataan-perkataan") diterjemahkan $\epsilon \nu \tau 0 \lambda \alpha \varsigma$ dalam Septuaginta, yang sebenarnya lebih tepat diartikan "perintah-perintah". Baik kata דִִִּ maupun $\epsilon \nu \tau 0 \lambda \alpha \varsigma$ sama-sama bernumerik jamak. Dengan demikian, kata הַת yang bernumerik tunggal tidak diterjemahkan oleh penerjemah Septuaginta. Jika begitu, teks Ibrani yang tepat seharusnya, הרברים האלה. Dalam kodeks Ambrosianus, yang berasal dari abad ke-5 M, frasa tersebut dituliskan dalam huruf kecil ( $\boldsymbol{\sigma}^{\mathrm{Fmin}}$ ). Dan

\footnotetext{
${ }^{5}$ Lihat pada bagian Analisis Sastra dan Sumber (poin 3.2.1), hal 66.
} 
bentuk terjemahannya adalah sebagai berikut: $\tau \alpha \varsigma \in \nu \tau 0 \lambda \alpha \varsigma$ $\alpha \cup \tau o u$. Solusi yang terbaik ialah memperhatikan ayat ini secara utuh, maka terjemahan BHS adalah yang lebih tepat. Terjemahan LAI pun mengikuti versi BHS. Argumentasinya, raja Israel seharusnya memegang perkataan-perkataan dari Taurat yang selalu ada di sampingnya, dan membaca perkataan itu seumur hidup. Jadi, kesannya lebih tegas kepada isi Taurat itu sendiri. Sehingga kata atau istilah "Taurat" pun harus ada.

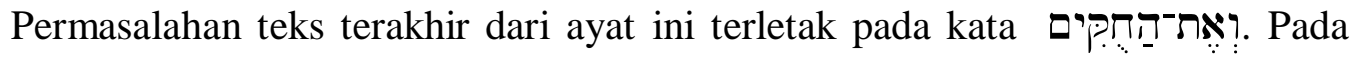
bacaan berbeda dari kodeks tulisan tangan Ibrani no.69 menurut Kennicott dan Targum Pseudo-Yonatan menaruh preposisi כל כלāl): "seluruh/ setiap" sebelum kata

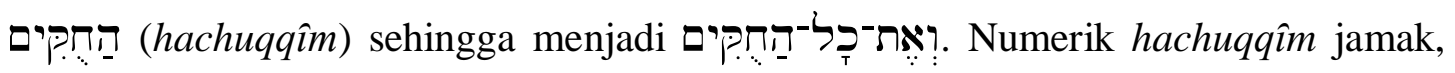
dan bentuk itu sudah menunjukkan jumlah ketetapan yang harus dibaca raja. Tanpa kata $k \bar{a} l$ pun, maknanya tetap jamak. Lagipula pada terjemahan lain, tidak terdapat penambahan seperti pada terjemahan $\mathrm{V}^{\mathrm{Ken} 69}$ dan $\mathbb{C}^{\mathrm{J}}$. Jadi, sebaiknya tetap memakai teks BHS. Dan penulis mengajukan hasil kritik teks ayat ini demikian:

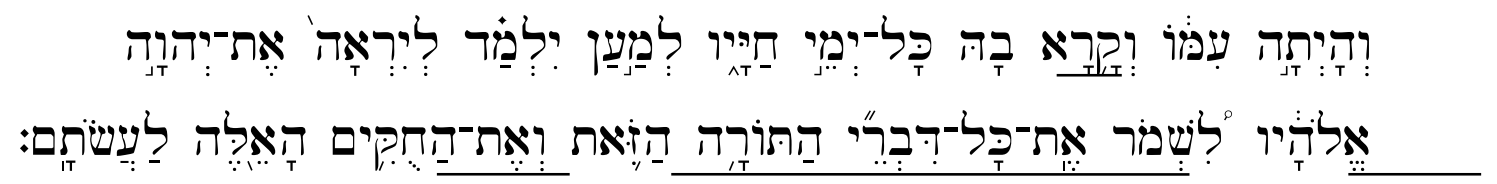

Ayat 20

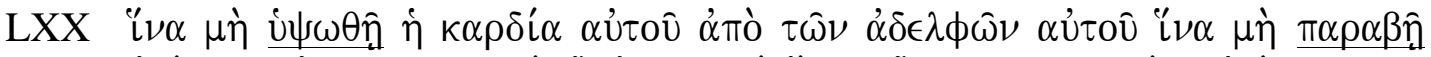

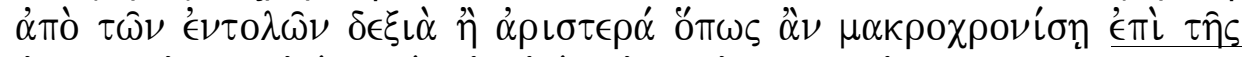

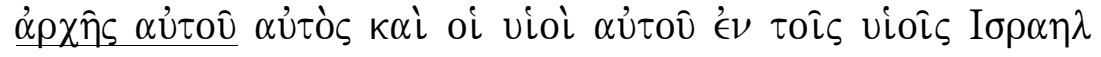


ITB Supaya jangan dia menjadi tinggi hati terhadap saudara-saudaranya, dan juga jangan menyimpang dari perintah ke kanan dan kiri. Sehingga dia memperpanjang hari-hari atas tahta kerajaannya, dia dan keturunannya di tengah-tengah Israel.

Berdasarkan pada penelitian apparatus, ayat ini mempunyai tiga permasalahan teks.

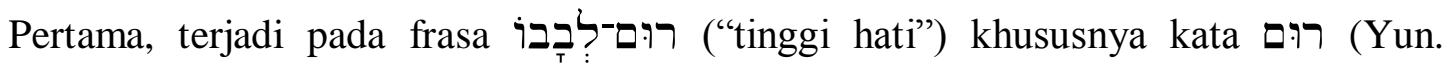
$u \psi \omega \theta \hat{y})$, berarti "menjadi tinggi”. Kata ini di dalam terjemahan Pentateukh Samaria berbentuk רפ. Sedangkan di dalam kodeks-kodeks tulisan tangan menurut perangkat penelitian dalam buku A. Von Gall dituliskan ראם. Permasalahan yang sama juga

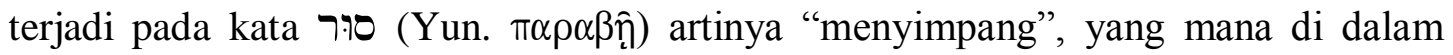
Pentateukh Samaria dituliskan סר, tanpa memakai huruf פ. Gramatika kata רוּם dan kata 0 adalah qal.inf.cstr. Barangkali penyalin Pentateukh Samaria menganggap huruf 9 memang tidak ada dalam teks aslinya. Namun pada saksi-saki (terjemahan) lainnya, bentuk kedua kata ini tidak berbeda jika dibandingkan dengan teks BHS. רarena itu, penulis tetap mengikuti teks BHS dengan tetap menggunakan kata dan kata סו: סור.

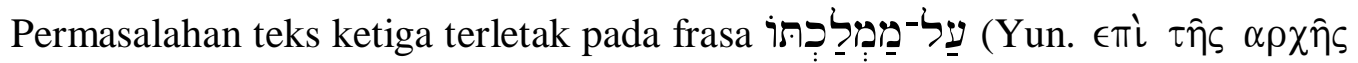

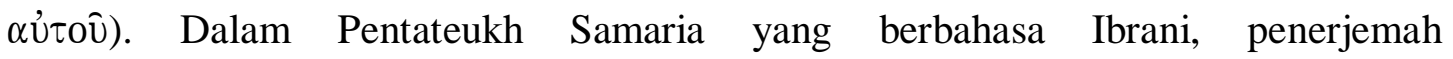

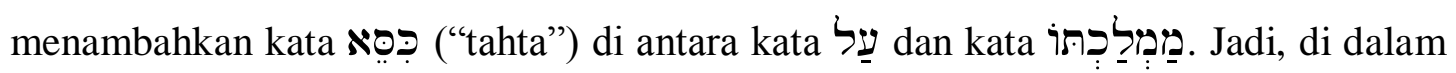

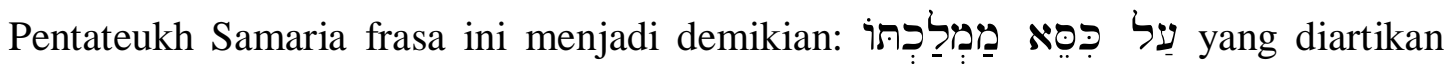
"atas tahta kerajaannya". Kemungkinan penerjemah Pentateukh Samaria ingin 
memparalelkan bagian ini dengan ayat 18 (lih. hal.54), di mana kata kissēe dicantumkan pula. Sehingga kedua frasa ini pun menjadi seirama. Hal ini bertujuan untuk menjelaskan bahwa yang akan bertahan lama di tengah-tengah orang Israel, bila raja melakukan Taurat adalah "tahta kerajaan”-nya. Bukan hanya raja yang bersangkutan akan lama memerintah, tetapi berlaku juga bagi keturunannya. Karena itu, kata kissē' sebaiknya memang dituliskan. Sementara itu, terjemahan LAI mengikuti teks Masora dan terjemahan Septuaginta. Dengan demikian, hasil kritik teks terhadap ayat 20 ini adalah:

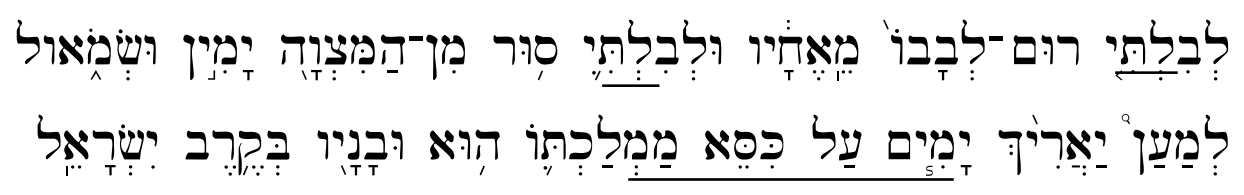

Berdasarkan hasil analisis teks yang detail di atas, maka kini bisa dibuat terjemahan harfiah untuk nats Ulangan 17:14-20 secara utuh adalah sebagai berikut:

(14) Apabila engkau telah tiba ke negeri (itu) yang TUHAN, Allahmu berikan kepadamu menjadi milik pusaka, dan telah memilikinya dan diam di sana, kemudian engkau berkata: Aku mau mengangkat seorang raja atasku, seperti seluruh bangsa yang di sekelilingku.

(15) Engkau hanyalah (boleh) mengangkat atasmu seorang raja yang TUHAN, Allahmu akan memilih bagi-Nya. Dari antara saudarasaudaramu engkau akan mengangkat atasmu raja. Engkau tidak boleh mengangkat atasmu orang asing, yang bukan saudaramu.

(16) Hanya, dia jangan memelihara banyak kuda untuk dirinya sendiri, dan jangan mengembalikan bangsa ini ke Mesir dalam rangka memperbanyak kuda untuk dirinya sendiri. Sebab TUHAN, Allahmu telah berfirman kepadamu (sekalian): Jangan pernah kamu sekalian kembali melalui jalan ini lagi.

(17) Dan janganlah dia mempunyai banyak istri bagi dirinya, supaya hatinya jangan menyimpang. Lalu perak dan emas janganlah dia miliki terlalu banyak untuk dirinya sendiri. 
(18) Dan ketika dia duduk di atas tahta kerajaannya, ia akan menulis bagi dirinya sendiri salinan hukum ini, menurut kitab yang dipegang para imam Lewi.

(19) Itulah yang harus ada dengannya, dan dia akan membaca(isi)nya seumur hidupnya supaya dia belajar takut akan TUHAN, Allahnya dengan berpegang pada seluruh perkataan hukum dan ketetapan-ketetapan ini, serta melakukannya.

(20) Supaya jangan dia menjadi tinggi hati terhadap saudara-saudaranya, dan juga jangan menyimpang dari perintah ke kanan dan kiri. Sehingga dia memperpanjang hari-hari atas tahta kerajaannya, dia dan keturunannya di tengah-tengah Israel. 